\title{
ATYPICAL FORMS OF WORK AND BUSINESS IN THE CREATIVE INDUSTRY OF THE EUROPEAN UNION
}

\author{
Ivana Ljevak Lebeda \\ PhD, Director, Naklada Ljevak Ltd, Chromosov toranj Ulica grada Vukovara 271, 10000 Zagreb, Croatia; \\ e-mail: ivana.ljevak@naklada-ljevak.hr
}

\section{Kornelija Mlinarević}

M. Econ., Head of Department for EU Programs Projects at City of Osijek, City of Osijek, Kuhačeva 9, 31000 Osijek, Croatia; e-mail: kornelija.mlinarevic@osijek.hr

\section{Jasna Horvat}

PhD, Full professor, Facult of Economics Osijek, University of Osijek, Trg Ljudevita Gaja 7, 31000 Osijek, Croatia; e-mail:jasna@efos.hr

\begin{abstract}
Starting from the insight into atypical forms of work as well as new / alternative business models specific to the creative industry $(\mathrm{Cl})$ sectors of the European Union, the paper researches self-employment in the creative industry and volunteering as a prerequisite for self-employment. The creative industry is considered as industry of economically developed countries as well as the prototype industry, whose "recipes" are multiplied in underdeveloped countries and thus materialized for mass distribution. The methodology of the work applied three different groups of methods adapted to hypotheses. The first hypothesis states that EU research indicates business constraints / characteristics in the creative industry. In order to test this hypothesis by meta-analysis of the collected sources, key business constraints in the creative industry were separated, and then atypical forms of work emerged from them. The second hypothesis was tested by descriptive and bivariate statistical analysis of secondary data. It is about analyzing secondary data in a newly formed file constructed for the purposes of this research. The file combines secondary sources of data on cultural statistics (European Union) and GII Global Innovation Indices (WIPO), which were used to test the hypothesis that self-employment as an atypical form of work in culture is related to the level of the Global Innovation Index (GII).
\end{abstract}

Key words: creative industry, business models, meta analysis, atypical forms of work, secondary data

JEL classification: $01, \mathrm{Z1}$ 


\section{INTRODUCTION}

Since the beginning of this millennium, the creative industry $(\mathrm{Cl})$ has been systematically encountered in highly developed countries or communities (such as the European Union) and has become synonymous with business activities based on knowledge, innovation and creative projects, and protected by copyright.

Creative industry companies in most EU countries recorded overall growth (+ 4.3\%) between 2008 and 2016 and reached at least a 10\% share in the total number of companies in the business services sector (2.45 million companies in 2016), whereby the total employment in the EU creative industry amounted to more than 6.7 million employees in the same year of 2016. (KEA \& PPMI, 2019).

The EU Commission has defined industry in general in this millennium as "the backbone of the European economy. Europe's global competitive advantage in high value-added products and services translates to more than $20 \%$ of the EU's total value-added, with industry directly providing 35 million jobs. Competitiveness is therefore at the heart of the Commission's agenda and, as we stand on the brink of a new industrial revolution, we are committed to supporting the digital and green transformation of EU industry."1

Thus, the EU defines industry and the related industrial strategy is based on achieving "global competitiveness, reach climate-neutrality by 2050 , and make Europe fit for the digital age" ${ }^{\prime 2}$, that is, on the development of its own ideas and innovation.

Given that the basic product of the creative industry is knowledge, idea and a copyrighted prototype - a "recipe" suitable for future reproductions relocated to less developed communities, the creative industry occupies an important place in the projection of the future of the EU. This thesis is confirmed by numerous documents of the EU Commission and publicly available information on the conducted research of the creative industry advertised on the website of the EU Commission. ${ }^{3}$

Searle (2017: 6) explain „Copyright is a key intellectual asset for these industries ${ }^{4}$, and they account for the majority of copyright policy." Horvat et al. (2018: 14) define the creative industry as an industry that "implies copyright-protected production [which is] and is covered by projects for the production of intangible products and services intended for market exchange." The same authors propose for the Republic of Croatia a creative industry based on twelve sectors (Figure 1).

1 https://ec.europa.eu/growth/industry_en, accessed April 5, 2020

2 The European Commission "supports the transformation of the EU's energy-intensive industries to enable a climate-neutral circular economy by 2050; strengthening the skills of citizens to participate in industry; promotion of advanced technologies; support for innovation through policies and programs; taking measures to protect intellectual property in order for companies to better manage and benefit from their intangible assets;..." (https:// ec.europa.eu/growth/industry_en, accessed April 5, 2020)

3 https://ec.europa.eu/culture/policy/cultural-creative-industries_en, accessed April 5, 2020

4 The author uses the term "creative industries" in the original, which will be translated in the singular (creative industry) in this paper in order to avoid terminological confusion. 
Figure 1. Creative industry sectors in the Republic of Croatia

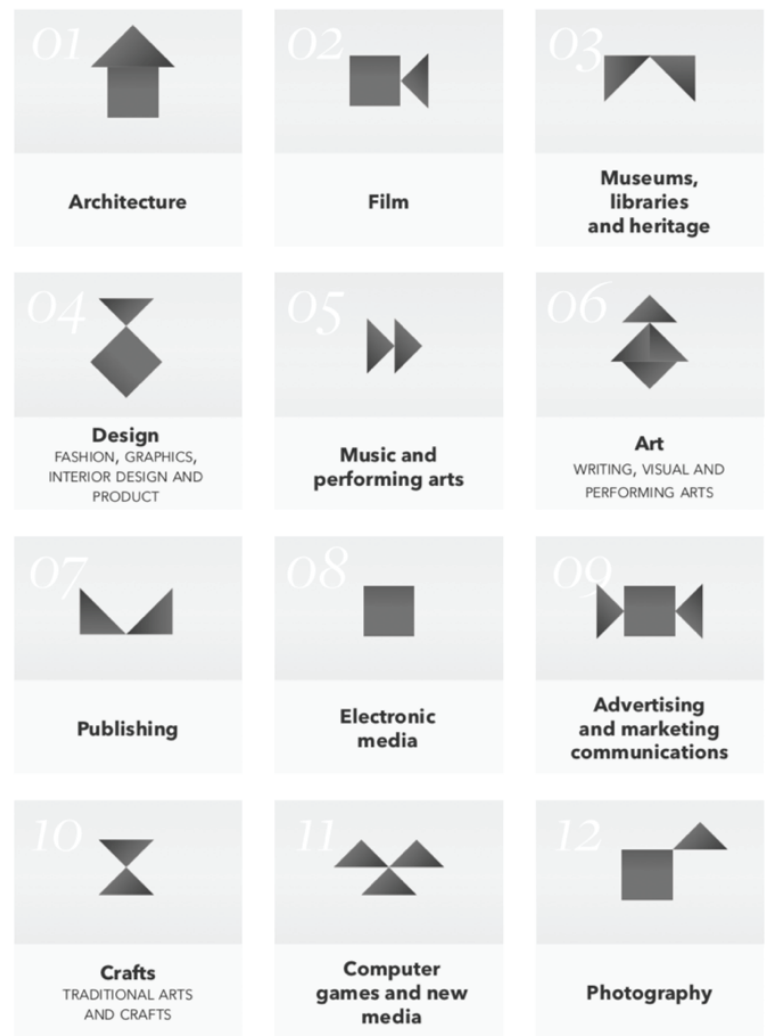

Source: Horvat et al., (2018:15)

Precisely because of all the above, the development of the creative industry is an indicator of the level of development of the local or national community, and the ordinances and regulations governing the creative industry contribute to its further growth. Searle (2017: 5) warns to „the terminology used to describe the $\mathrm{Cl}$ has varied over time. In the last thirty years it has moved from the copyright industries, to variations on creative economy, cultural economy, cultural industries, creative industry and culture, and creative and cultural industry."

That it is still an industry that is just being institutionalized is also shown by the fact that only a certain number of authors (Harwiki et al., 2020; Ihani et al., 2020; Majdúchová \& Barteková5, 2020; Waldfogel, 2020; Horvat et al., 2018) call the creative industry ${ }^{6}$ singular instead of plural (cultural and creative industries). Horvat et al. (2018) propose that the creative industry to be institutionalized in accordance with Scheme 1 and that 12 sectors of which the heritage sector (museums, libraries

5 In Slovakia, the creative industry has been officially called in the singular since 2012 (https://en.unesco.org/creativity/ policy-monitoring-platform/creative-industry, accessed: 5 April 2020).

6 The Cambridge Dictionary contains the following description of the creative industry: "an industry that is based on work in which original ideas are important, such as work in the arts or the media, in designing computer software, etc. It is recognized that the creative industries possess significant economic potential. (accessed: April 5, 2020). 
and archives) is predominantly cultural sector be structurally harmonized similar to sector harmonization in all other industries. They emphasize that, for example, the processing industry in the Republic of Croatia contains 14 components (sectors), but it is a single industry, not 14 different industries. Furthermore, as stated by Innerhofer et al. (2018:3) "creative industries is also a result of their interdependent relationship with non-creative, traditional businesses and... the landscape of increased connectivity, complexity, and growth, based on continued digitization, influences and changes creative industries. This could be interpreted as both a challenge and an opportunity for new business models within the creative sectors."

That the EU creative industry is facing institutional and organizational challenges is also confirmed by the research that the EU undertakes and the regulations that harmonize the activities of the cultural and creative sectors of the EU creative industry. Given that this information is publicly available, their publication shows the desire to create an open society "society open to innovation?, or change that occurs as a result of achieving and introducing innovative theories and practices." (Horvat et al., 2018: 113).

The creative industry is characterized by a high degree of innovation, technological development within the project activity protected by copyright and processes in which the finding (invention) becomes an innovation only after it is transformed into a product or service.

„In the contemporary world, innovative activity is a vital factor of competitiveness and long-term economic growth of a country... In the age of globalisation, implementation and commercialisation of new technologies are perceived as key elements determining competitiveness of particular countries." (Roszko Wójtowicz \& Białek, 2019: 268).

All of the above requires the adaptation of traditional business models, and then the introduction of atypical forms of work and business that develop from established business models in the creative industry.

\section{PREVIOUS RESEARCH}

Business model change is essential for success. Achtenhagen et al. (2013)

Previous research relevant to this paper has been considered with the aim of determining the business characteristics of $\mathrm{Cl}$, the prevailing business models of this industry and the employment models. In addition, innovation is considered because innovation is identified as a key determinant of $\mathrm{Cl}$ (Petrova, 2018) and it is studied within the WIPO ${ }^{8}$ research (Strazdas et al., 2013) taking into account the Gll (Global Innovation Index - English Innovative Index) which measures the innovation of 127 countries based on 81 indicators. Gll indicators are divided into two sub-indices (innovation input sub-index and innovation output sub-index) and include

7 Horvat, Mijoč \& Ljevak Lebeda (2018: 113) state that "Innovation is often associated with the concepts of inventions (lat. Inventio - invention) and creation (lat. Creatio - birth, creation) which are only components of the concept of innovation lat. inovatio - novelty, invention). Creativity is the starting point of every invention (invention), but invention is only a transitional step towards innovation. "

8 WIPO - World Intellectual Propery Organization 
input sub-indices: institutions, human capital and research, infrastructure, market sophistication, business sophistication, and output sub-indices: scientific outputs, creative outputs. ${ }^{9}$

$\mathrm{Cl}$ business models are being developed within the framework of legislation that regulates the operations of the $\mathrm{Cl}$ sector and raises issues of influence to which they are exposed.

„Cultural and creative industries ${ }^{10}$ have been recently affected by the broader economic, social and structural changes that are influencing not only the academic debate around cultural and creative industries but also their governance and management models" (Innerhofer et al., 2018: 1). Strengthening the $\mathrm{Cl}$ shows that its organizational systems are also changing. Thus Strazdas and co-workers describe the innovation of the system as "one type of innovation when the creative process results in the development of a new system, the individual elements of which are not new but the novelty appears in the novel composition, integration and new relations between these elements" (Strazdas et al., 2013: 2). The same authors state that determining the innovative procedure is specially important in $\mathrm{Cl}$ where the process of confirming innovation achieved in business is often very complex.

Searle (2017) examines business models in the Creative Industry $(\mathrm{Cl})$ applies the Baden-Fuller (2016) business model taxonomy to the $\mathrm{Cl}$. The adapted Searles taxonomy of KI business models contains four elements: product and service model, solutions model, matchmaking model and multi-sided model (Table 1).

Table 1. Searles' taxonomy of business models of $\mathrm{Cl}$

\begin{tabular}{|c|c|c|c|}
\hline Models & The goal of the company & $\begin{array}{c}\text { Type of connection } \\
\text { (businesses and consumers) }\end{array}$ & $\begin{array}{c}\text { Example of a } \\
\text { company }\end{array}$ \\
\hline Product and service & $\begin{array}{c}\text { the sale or licensing of } \\
\text { standardized goods and } \\
\text { services }\end{array}$ & dyadic ${ }^{11}$ & $\begin{array}{c}\text { most } \\
\text { common in } \mathrm{Cl}\end{array}$ \\
\hline Solutions & $\begin{array}{c}\text { tailor the solution to each } \\
\text { customer }\end{array}$ & dyadic & $\begin{array}{c}\text { a consulting } \\
\text { firm }\end{array}$ \\
\hline Matchmaking & dacilitate exchange & dyadic & $\begin{array}{c}\text { auction } \\
\text { houses }\end{array}$ \\
\hline Multi-sided & $\begin{array}{c}\text { multilateral exchange of } \\
\text { values, consumers get } \\
\text { added value from each } \\
\text { other }\end{array}$ & $\begin{array}{c}\text { newspapers } \\
\text { (readers } \\
\text { are both } \\
\text { advertisers } \\
\text { and } \\
\text { consumers) }\end{array}$ \\
\hline
\end{tabular}

Source: Searle (2017: 18-19)

9 WIPO, https://www.globalinnovationindex.org/home, accessed: April 17, 2020

10 The original author uses the term cultural and creative industries.

11 The relationship between the two parties (company-customer) dominates.

12 The company establishes a relationship with consumers, but also customers establish mutual relations. 
In interpreting Cl's business models, Searle (2017: 19) refers to Baden-Fuller, who notes that „the external relationships between business models, via competition, can be observed within business models, between models, and can manifest competition and cooperation in a variety of models."

From all the above, it can be seen that the unavoidable specificity in the business of $\mathrm{Cl}$ is related to copyright protection (copyright e. g. Intellectual property, IP) ${ }^{13}$, which is also a limitation in business, especially if we take into account numerous copyright infringements.

However, while different authors argue if IP and copyrights matters lead to changes in business models the digital era has indisputably transformed production and distribution technologies and affected their transaction costs. (Kaye, 2013; Doyle, 2017; Searle 2017).

It is important to emphasize the role of digital technology in all sectors of Cl. Searle (2017) notes that digital technology is present even in the "non-digital sectors" of $\mathrm{Cl}$ (performing arts, fashion, and design) because despite the fact that these sectors have not undergone a complete digital transformation in these sectors, advertising and sales in these sectors are achieved using digital technology and online. According to the same author, the digital exchange of information and content in the consumer-producer relationship further complicates the protection of producers' copyright and is particularly complex in multilateral exchange models (Table 1).

Landoni et al. (2019) shows that the application of business innovation must be adapted to the development phase of the enterprise. The same authors state that in the ascending phase of the company innovative solutions are focused on overcoming limited resources (with the aim of building a recognizable reputation of the company), that in the development phase they focus on innovative forms of distribution, and in the maturity phase on creating development platforms. In doing so, the authors warn of the ambivalence of digital technologies, but also tangible assets in their impact on innovative transformations of business models. Namely, although the lack of tangible assets can be a driver for innovative reorganization of companies as well as the use of advanced, digital technology can produce new, unexpected bottlenecks for which it is necessary to ensure rapid change.

As the creative industry relies entirely on knowledge, innovation and creation, its key components are employees (creative workers, creative class) who often come from the field of culture, and the forms of work include self-employment and volunteering, which will be the subject of metaanalysis below, in the next part of this paper.

\section{METHODOLOGY}

The methodology applied in the paper relies on a meta-analysis of research studies (European Union and WIPO) and on a statistical analysis (descriptive and bivariate) of secondary data collected for European Union countries.

${ }_{13}$ Copyright (intellectual property, IP) is not discussed in detail in this paper because it is primarily related to legal science. 
Table 2. Research studies used in meta-analysis

\begin{tabular}{|l|c|c|c|}
\hline Publication & Year & Publisher & Access \\
\hline Cultural and creative industries & Permanent & $\begin{array}{c}\text { European } \\
\text { Commission }\end{array}$ & https://bit.ly/2XjEfil \\
\hline $\begin{array}{l}\text { Internal Market, Industry, } \\
\text { Entrepreneurship and SMSs 2018 }\end{array}$ & 2019 & $\begin{array}{c}\text { European } \\
\text { Commission }\end{array}$ & https://bit.ly/2XyOxeP \\
\hline $\begin{array}{l}\text { The Creative Skills Europe (series) } \\
\text { - a Step ahead - Training for innovation } \\
\text { - a Safe Bet - Training and workforce } \\
\text { development } \\
\text { - it is a new world - Training in and for } \\
\text { the digital era }\end{array}$ & 2019 & $\begin{array}{c}\text { European } \\
\text { - Joining forces - funding our Training } \\
\text { needs } \\
\text { - fruitful co-operations - access to } \\
\text { training through Social dialogue }\end{array}$ & https://bit.ly/3cWmQCV \\
\hline $\begin{array}{l}\text { Cultural statistics } \\
\text { Union - key future developments, } \\
\text { challenges and opportunities }\end{array}$ & 2019 & KEA \& PPMl \\
\hline $\begin{array}{l}\text { Research for CULT Committee - Culture } \\
\text { alture statistics }\end{array}$ & Permanent & Eurostat & https://bit.ly/2XqSqCu \\
\hline
\end{tabular}

Source: Authors

As Table 2 shows, the meta-analysis includes three research studies from 2019, a series of educational manuals from 2019 and two European Union websites where new knowledge about doing business in $\mathrm{Cl}$ is systematically published.

The methodology based on descriptive and bivariate analysis of secondary data (European Union and WIPO) was implemented by building a new file that consolidated the secondary data taken from former studies. These are the following data sources:

a) Employment in culture: self-employed persons in 2018 (total, men and women, data in \%) $)^{14}$

b) Gll (Global Innovation Index) points and rank for $2018^{15}$

c) GIl (Global Innovation Index) points and ranking for $2019^{16}$

14 Eurostat, Cultural statistics 2019. Accessed: https://ec.europa.eu/eurostat/documents/3217494/10177894/KS-0119-712-EN-N.pdf/915f828b-daae-1cca-ba54-a87e90d6b68b

15 WIPO, Accessed: https://www.wipo.int/edocs/pubdocs/en/wipo_pub_gii_2018.pdf

16 WIPO, Accessed: https://www.globalinnovationindex.org/userfiles/file/reportpdf/gii-full-report-2019.pdf 
Secondary data were pooled in a new file to test the research hypothesis that atypical forms of work in culture as part of the creative industry are related to the height of the Global Innovation Index (GII). In doing so, it is important to state the way in which the GIl index is constructed.

„The innovation efficiency at the macro level Gll is calculated as the ratio of the country's contribution to the development of innovations - Innovation Input Sub-Index and the output of the innovation development - Innovation Output Sub-Index. The results show that the innovation efficiency is very different. This means that some countries are using the resources for the innovation development more efficiently than others. A similar situation is observed at the firm level." (Strazdas, Cerneviciute \& Jancoras 2013:2).

The methodological construction of the Gll index is shown in Table 3.

Table 3. Methodological construction of the GII (Global Innovative Index)

\begin{tabular}{|c|c|c|c|}
\hline Sub-index & Sub-pilar & & nents \\
\hline \multirow{15}{*}{$\begin{array}{l}\text { Innovation Input } \\
\text { Sub-Index } \\
\text { (the simple average } \\
\text { of the first five sub- } \\
\text { pillar scores) }\end{array}$} & Political environment & \multirow{3}{*}{ Institutions } & \multirow{15}{*}{$\begin{array}{c}\text { Elements of the } \\
\text { national economy } \\
\text { that enable } \\
\text { innovative activities }\end{array}$} \\
\hline & Regulatory environment & & \\
\hline & Business environment & & \\
\hline & Education & \multirow{3}{*}{$\begin{array}{l}\text { Human capital } \\
\text { and research }\end{array}$} & \\
\hline & Tertiary education & & \\
\hline & Research and development & & \\
\hline & ICT & \multirow{3}{*}{ Infrastructure } & \\
\hline & Energy & & \\
\hline & General infrastructure & & \\
\hline & Credit & \multirow{3}{*}{$\begin{array}{c}\text { Market } \\
\text { sophistication }\end{array}$} & \\
\hline & Investment & & \\
\hline & Trade and competition & & \\
\hline & Knowledge workers & \multirow{3}{*}{$\begin{array}{c}\text { Business } \\
\text { sophistication }\end{array}$} & \\
\hline & Innovation linkages & & \\
\hline & Knowledge absorption & & \\
\hline \multirow{6}{*}{$\begin{array}{l}\text { Innovation Output } \\
\text { Sub-Index } \\
\text { (the simple average } \\
\text { of the last two } \\
\text { pillar scores) }\end{array}$} & Knowledge creation & \multirow{3}{*}{ Scientific outputs } & \multirow{6}{*}{$\begin{array}{c}\text { Evidence of } \\
\text { innovation outputs }\end{array}$} \\
\hline & Knowledge impact & & \\
\hline & Knowledge diffusion & & \\
\hline & Creative intangibles & \multirow{3}{*}{ Creative outputs } & \\
\hline & Creative goods & & \\
\hline & Services outputs & & \\
\hline
\end{tabular}


Given that the Gll consists of two sub-indices (innovation input and innovation output), it is important to emphasize that in the analysis of this paper, points for 2018 and points for 2019 were used, which in both cases were calculated as the unweighted arithmetic mean of the input and output. In addition to the above indicators, the analysis also used the ranking of countries that countries have achieved in the observed years in the global ranking of countries in terms of innovation. Bivariate statistical analysis of aggregated secondary data for EU countries was applied to the constructed data, ie Pearson's correlation test was calculated, with the aim of determining the relationship between the level of self-employment in cultural activities of EU member states in 2018 and the level of GII.

\section{RESULTS}

A meta-analysis of research studies (Table 2) examined the assumption that European Union research studies draw conclusions about atypical forms of work and business in $\mathrm{Cl}$ (Table 1).

Employees (creative workers, creative class) are a key element of the creative industry. On the European Union's website dedicated to the analysis of the cultural and creative sectors (CCS - culture and creative sectors) of the creative industry, a special chapter has been singled out Changing skills - which describes the skills and abilities of employees in Cl. It is stated there that „As the culture sector evolves and changes, so do the skills required of individuals active in the sector. The educational and training needs created by these changes can only be met by an education sector that recognises the change in demand."17

The optimistic prediction that the education sector recognizes the challenges of the new age has been somewhat denied by a European Commission study that states that „CCS' professionals increasingly require a blend of creative, digital, managerial and entrepreneurial competences, coupled with soft skills to stimulate innovation. The contribution of CCS to developing trans-sectorial soft and creative skills becomes even more critical in the age of Artificial Intelligence (Al) and the automation of work" (KEA \& PPMI, 2019: 7). The latter quote does not indicate that educational processes have adapted to the needs of the creative industry, but points to the need for lifelong learning to adapt the work of heterogeneous creatives to extremely rapid technological and market changes. The same research warns of the need to measure in order to determine how well the existing labor market rules correspond to a highly fragmented work environment and how often social security is applied to atypical forms of work (self-employed) in the creative industry. With regard to skills and education, there is a need to encourage skills development and lifelong learning programs that will „include a clear component for culture and creativity" and "programmes integrating the arts into STEM curricula", „the development of a CCS literacy policy", as well as development of „programmes for entrepreneurship, investEU programme, monitoring the level of public support for culture and "Incentivise the CCS to take up an active role in terms of environmental sustainability" (KEA \& PPMI, 2019: 9).

17 https://ec.europa.eu/culture/policy/cultural-creative-industries/skills_en, accessed April 5, 2020 
The European Commission has issued five publications united under the title The Creative Skills Europe series (2019) with the aim of "inspiring businesses and professionals from the European creative sectors to engage in training and develop customized solutions for skills development and career management." The publications address the key issues of the creative workforce in the EU, namely innovation, workforce development, work "in" and "for" the digital era, and ways to join forces to find tools to improve workers' skills. The second volume of these publications (Joining forces - Funding our Training needs) states the problem of atypical employment in the field of $\mathrm{Cl}$. "Many of the professionals making up the sector are short-term employees or independent workers (self-employed, freelancers, etc.) and a large proportion of the businesses have ten or less employees on the payroll. This means that structured HR policies and training strategies can often be inaccessible, and that professional training opportunities therefore should be offered across the sector in order to develop schemes and tools for all types of creative businesses and workers."18

In other words, the creative enterprise market is shaped by a limited (smaller) number of large stakeholders and a multitude of small enterprises forced to innovate the production and content they produce in a digital environment for market competition. Creative workers in certain phases of their work produce innovative solutions, but with the assumption of constantly monitoring the development of technologies, learning about the digital environment and creating original, own solutions. The European Commission also emphasizes the importance of cultural and creative work in its publication Internal Market, Industry, Entrepreneurship and SMSs 2018 (2019: 35), which states that the role of "cultural and creative sectors in the context of the renewed Industrial Policy Strategy... at EU level... with the aim to investigate how creative sectors generate innovations that make a positive impact in other sectors and help boosting the competitiveness of the economy." Given that creative enterprises are largely organized as medium and small (SMEs), it is important to point out that the same publication identified $89 \%$ of SMEs "are expected to improve this market situation through network support. Nearly one in two SMEs is likely to achieve their competitiveness by increasing the greater innovation achieved in the Enterprise Europe Network (EEN). Nearly 6 out of 10 SMEs will estimate that network services will help them preserve and create jobs. Based on the positive results of its first two years within $\operatorname{COSME}^{19}$ and on 10 years of experience we have supported SMEs, EEN has prepared new strategies for strategic visions to adapt their services to changing business opportunities and to increase the positive impact on small and medium enterprises. Based on the positive results of its first two years under COSME and on its 10 years of experience with providing support to SMEs, the $\mathrm{EEN}^{20}$ is preparing the implementation of its new strategic vision to adapt its services to changing business needs and to further increase the positive impact on SMEs" (European Commission, 2018: 17).

Considered from the perspective of the Labor market area, two scenarios are identified: aspirational and disruptive scenarios. An aspirational scenario foresees the following possibilities (listed from

\footnotetext{
18 http://www.creativeskillseurope.eu/wp-content/uploads/2018/11/CSE-series_Training-and-workforcedevelopment-1.pdf, 2019: 10

19 COSME - Competitiveness of enterprises and small and medium-sized enterprises programme. COSME also supported the Intellectual Property Rights (IPR) Helpdesk.

20 The Enterprise Europe Network (EEN) is present in 69 countries, assisting about 250.000 Small and Medium Enterprises (SMEs) yearly to internationalise.
} 
the most-likely ones to the least-likely ones): „The CCS will ensure an advanced position in the society by remaining up to date with the latest trends. In the next ten years, transnational mobility of the European CCS professionals will further increase. CCS freelancers and in other atypical types of work will obtain more access to social security benefits and will increase their work security. CCS professionals will obtain easier access to non- national markets. Creativity and arts will increase their" (KEA \& PPMI, 2019: 98).

A disruptive scenario, on the other hand, opens the possibility to the following negative expectations (listed from the most-likely ones to the least-likely ones): „Employees of the CCS will continue being pushed into unfavourable economic and social conditions. Culture and arts will be governed by and performing for elites. In the next ten years, transnational mobility of the European CCS professionals will still be restricted by national and EU regulation (such as lack of progress on visa liberalisation issues, etc.)“ (KEA \& PPMI, 2019: 98).

The European Commission's Cl website (https://ec.europa.eu/culture/policy/cultural-creativeindustries/market-finance_en, accessed: April 17 2020) points out that $\mathrm{Cl}$ is a highly variable business, in terms of both the size of the company and the resources, connections and market reach, and especially the non-harmonized regulations across the EU (related to taxes, business and intellectual property). In the same network place, the complicated one stands out in particular for „access to finance and, thus, markets remain problematic for several reasons:

- Lack of expertise in financial institutions to analyse CCl business models;

- Poor valuation among financial institutions of the intangible assets of CCls;

- Lack of data and statistics;

- Complexity of culture sector business plans and models."

Unlike $\mathrm{Cl}$, for which there are no unambiguous indicators and measurements in the EU, the cultural sector (which according to most nomenclatures is also part of $\mathrm{Cl}$ ) has longer sets of secondary statistics based on which the conclusions are drawn. „In 2018, there were 8.7 million people across the EU-28 working in a cultural activity or a cultural occupation (the definition employed by Eurostat to delineate cultural employment is presented below in the section on Methodological notes). These 8.7 million persons employed were equivalent to $3.8 \%$ of the total number of persons employed within the whole of the EU-28 economy" (Culture statistics, 2019: 63).

Volunteer work is perceived as an inevitable and often unwanted form of work in CCS, as well as an atypical form of employment as a self-employed person (freelancer). „It is likely that the trend of practicing atypical forms of work (see section 2.3) by the CCS organisations will continue in the next 10 years. Atypical forms of work demonstrate the flexibility, openness and creativity of the sector. At the same time, when not chosen voluntarily, they can be a result of unhealthy work climate and unjust labor conditions. Without the necessary policy actions/ changes, there is a risk that employees of CCS will continue being pushed into unfavourable economic and social conditions, facing low pay levels and lack of funding to support their artistic research" (KEA \& PPMI, 2019: 64). 
Based on the conducted meta-analysis of EU research studies, the first hypothesis was partially confirmed. As the meta-analysis shows, European Union research studies partly draw conclusions about atypical forms of work and business in $\mathrm{Cl}$. The reason why the first hypothesis was partially rejected is the result of inconsistent statistics in the countries of the European Union on the coverage of the activity and labor force of $\mathrm{Cl}$. Uneven statistics in $\mathrm{EU}$ countries are the reason why the EU fails to create long, stable sets of secondary $\mathrm{Cl}$ data.

To test the second hypothesis on the existence of a correlation between the number of selfemployed in cultural activities of the constituent countries of the European Union in 2018 and the amount of GII (2018 and 2019), a file was constructed based on secondary data sources (Table 4).

Table 4. Comparison of self-employed persons in culture in 2018 and the Global Innovation Index in 2018 and 2019

\begin{tabular}{|c|c|c|c|c|c|c|c|}
\hline \multirow{3}{*}{ Countries } & \multicolumn{3}{|c|}{$\begin{array}{l}\text { Cultural employment -self-employed } \\
\text { persons in } 2018\end{array}$} & \multicolumn{4}{|c|}{ Global Innovation Index } \\
\hline & \multirow{2}{*}{$\begin{array}{c}\text { Total } \\
\%\end{array}$} & \multirow{2}{*}{$\begin{array}{c}\text { Males } \\
\%\end{array}$} & \multirow[b]{2}{*}{ Females \% } & \multicolumn{2}{|c|}{2018} & \multicolumn{2}{|c|}{2019} \\
\hline & & & & $\begin{array}{c}\text { score } \\
(0-100)\end{array}$ & $\operatorname{rank}^{21}$ & $\begin{array}{l}\text { score } \\
(0-100)\end{array}$ & Rank \\
\hline Belgium & 30 & 35 & 23 & 50,50 & 25 & 50,18 & 23 \\
\hline Bulgaria & 18 & 25 & 13 & 46,25 & 37 & 40,35 & 40 \\
\hline Czechia & 37 & 40 & 33 & 48,75 & 27 & 49,43 & 26 \\
\hline Denmark & 18 & 22 & 15 & 58,39 & 8 & 58,44 & 7 \\
\hline Germany & 33 & 35 & 30 & 58,03 & 9 & 58,19 & 9 \\
\hline Estonia & 21 & 27 & 16 & 50,51 & 24 & 49,97 & 24 \\
\hline Ireland & 33 & 35 & 30 & 57,19 & 10 & 56,10 & 12 \\
\hline Greece & 35 & 36 & 34 & 38,93 & 42 & 38,90 & 41 \\
\hline Spain & 33 & 36 & 28 & 48,68 & 28 & 47,85 & 29 \\
\hline France & 29 & 33 & 25 & 54,36 & 16 & 54,25 & 16 \\
\hline Croatia & 12 & 14 & 10 & 40,73 & 41 & 37,82 & 44 \\
\hline Italy & 46 & 51 & 39 & 46,32 & 31 & 46,30 & 30 \\
\hline Latvia & 20 & 28 & 17 & 43,18 & 34 & 43,23 & 34 \\
\hline Lithuania & 18 & 22 & 15 & 41,19 & 40 & 41,46 & 38 \\
\hline Luxembourg & 18 & 17 & 18 & 54,53 & 15 & 54,37 & 18 \\
\hline Hungary & 24 & 26 & 21 & 44,94 & 33 & 44,51 & 33 \\
\hline Malta & 26 & 26 & 26 & 50,29 & 26 & 49,01 & 27 \\
\hline
\end{tabular}

21 This is the global rank of all analyzed countries, and not the rank related to the order of countries shown in Table 4 
I. Ljevak Lebeda, K. Mlinarević, J. Horvat: Atypical forms of work and business in the creative industry... Zbornik Veleučilišta u Rijeci, Vol. 9 (2021), No. 1, pp. 19-35

\begin{tabular}{|c|c|c|c|c|c|c|c|}
\hline Netherlands & 48 & 49 & 47 & 63,32 & 2 & 61,44 & 4 \\
\hline Austria & 30 & 34 & 26 & 51,32 & 21 & 50,94 & 21 \\
\hline Poland & 23 & 29 & 18 & 41,67 & 39 & 41,31 & 39 \\
\hline Portugal & 27 & 29 & 23 & 45,71 & 32 & 44,65 & 32 \\
\hline Romania & 13 & 18 & - & 37,59 & 49 & 36,76 & 50 \\
\hline Slovenia & 26 & 26 & 26 & 46,87 & 30 & 45,25 & 31 \\
\hline Slovakia & 29 & 31 & 28 & 42,88 & 36 & 42,05 & 37 \\
\hline Finland & 28 & 30 & 27 & 59,63 & 7 & 59,83 & 6 \\
\hline Sweden & 24 & 27 & 20 & 63,08 & 3 & 63,65 & 2 \\
\hline U. Kingdom & 37 & 38 & 36 & 60,13 & 4 & 61,30 & 5 \\
\hline Iceland & 31 & 35 & 28 & 51,24 & 23 & 51,53 & 20 \\
\hline Norway & 24 & 26 & 23 & 52,63 & 19 & 51,87 & 19 \\
\hline Switzerland & 31 & 37 & 25 & 68,40 & 1 & 67,24 & 1 \\
\hline
\end{tabular}

Insight into Table 4 shows that the largest number of self-employed persons in culture in 2018 was achieved by the Netherlands (the total number of self-employed persons in culture was $48 \%$, men $49 \%$, women 47\%). In 2018, the Netherlands was in second place in the global ranking of countries according to the achieved innovation index (Gll 63.32). In the same year, the highest innovation index was set for Switzerland (GII 68.40), followed by the Netherlands (GIl 63.32), Sweden (GIl 63.08) and the United Kingdom fourth (GII 60.13).

Further analysis of Pearson's correlation coefficient confirmed that there is a statistically significant correlation between the total number of self-employed in culture in 2018 and the level of Gll in 2018 $(r=0.377 ; p=0.04)$, but no correlation with the number of male self-employed in culture in 2018 year $(r=0.342 ; p>0.05)$, ie without connection with the number of women employed in culture in 2018 $(r=0.309 ; p>0.05)$.

On the other hand, Pearson's correlation coefficient showed that there is a statistically significant correlation between the total number of self-employed in culture in 2018 and the level of Gll for 2019 $(r=0.403 ; p=0.027)$ and the correlation between Gll for 2019 and by the number of self-employed men in in the culture (sector) $2018(r=0.365 ; p=0.047)$, but not the correlation to the number of self-employed women in the culture (sector) in 2018 ( $r=0.342 ; p>0.05)$. This data is taken with a grain of salt because the values from two consecutive periods are compared.

The second hypothesis was not rejected because it confirmed the statistically significant correlation of GIl in 2018 with the total number of self-employed persons in cultural activities of EU member states in 2018 and the number of employed men in cultural activities of EU member states in 2018. The recommendation for future related research is to determine the number of self-employed in the creative sectors of the European Union (and not only in the cultural sector) and to investigate the relationship between all self-employed employees and the level of Gll for the analyzed year or period. 


\section{DISCUSSION AND CONCLUDING REMARKS}

The creative industry confirms its innovative leverage in its own functioning. This is an industry of knowledge and conceptual solutions that is still not harmonized in the European Union with uniform regulations and nomenclatures, thus preventing the coverage of $\mathrm{Cl}$ statistics, ie the collection and analysis of harmonized secondary sub-acts on $\mathrm{Cl}$ of the European Union. On the other hand, the scientific and professional attractiveness of $\mathrm{Cl}$ is confirmed by numerous research papers which explore key elements of business in the creative industry (business constraints / characteristics) and atypical forms of work and business derived from $\mathrm{Cl}$ business models (Table 1).

The paper presents two hypotheses that were tested by two types of analyzes. The first hypothesis (European Union research studies draw conclusions about atypical forms of work and business in $\mathrm{Cl}$ ) was partially rejected. The reason for its partial rejection lies in the lack of comprehensive, uniform $\mathrm{Cl}$ statistics in the European Union. On the other hand, the meta-analysis of EU research studies provided insight into the existence of atypical forms of employment in $\mathrm{Cl}$ (from self-employment to volunteering) which are on the one hand the result of flexibility, openness and creativity of the $\mathrm{Cl}$ sector, and on the other hand of unfavorable economic and social circumstances in $\mathrm{Cl}$.

The second hypothesis (there is a correlation between the number of self-employed persons in the cultural activities of the EU member states and the GIl - Global Innovation Index) was not rejected. Based on the analysis of secondary data sources, a statistically significant association of GIl in 2018 with the total number of persons who were self-employed in the cultural activities of the European Union member states in 2018 was confirmed. At the same time, no statistically significant correlation was found between the level of Gll and the number of self-employed men and women.

The problem of coverage of all self-employed persons in $\mathrm{Cl}$ was noticed and it is recommended that future researchers repeat the analysis, but with the coverage of all self-employed persons employed in all sectors of $\mathrm{Cl}$, and not only in the cultural sector. In order to investigate in more detail the connection between Gll and the number of self-employed persons in the cultural or creative sectors of $\mathrm{Cl}$, it is necessary to conduct a longitudinal examination of the connection.

Given that the work was created during the COVID-19 pandemic, the sensitivity of $\mathrm{Cl}$ (especially atypical forms of employment in $\mathrm{Cl}$ ) to the global business context was also observed. In addition to numerous initiatives that sought to ensure the subsistence minimum of volunteers and the self-employed in $\mathrm{Cl}$, the cultural and creative sectors of $\mathrm{Cl}$ often offered free sharing of their own copyrighted content, as a form of volunteering both on a personal and institutional level, by giving the product for free consumption for a certain period.

Entrepreneurial, including voluntary initiatives that originated at the time of the COVID-19 virus are a thematic recommendation for future researchers. The need to overcome spatial constraints has opened new questions related to the operations of companies in $\mathrm{Cl}$ and the skill of using information technology, rapid response to adverse business circumstances and contribution to the process of strengthening an open society locally and globally. 


\section{REFERENCES}

Achtenhagen, L., Melin, L., \& Naldi, L. (2013) Dynamics of business models- strategizing, critical capabilities and activities for sustained value creation. Long range planning, 46(6), 427-442. https://doi.org/10.1016/j.lrp.2013.04.002

Cambridge Dictionary. Creative industry. Retrieved from: https://dictionary.cambridge.org/dictionary/english/creativeindustry. [April 5, 2020]

Crisci, F., Gon, M., \& Cicero, L. (2018) Managing a World Heritage Site in Italy as Janus Bifrons: A "Decentralized Centralization" Between Effectiveness and Efficiency. In Entrepreneurship in Culture and Creative Industries. (pp. 297-310). Springer, Cham. DOI: 10.1007/978-3-319-65506-2_17

CSE-series: Training and workforce develepoment. Retrived from: http://www.creativeskillseurope.eu/wp-content/ uploads/2018/11/CSE-series_Training-and-workforce-development-1.pdf.

Doyle, G. (2017). Digitization and changing windowing strategies in the television industry: negotiating new windows on the world. CREATe Working Paper Series DOI: 10.5281/zenodo.55755.

European Commision, Internal Market, Industry, Entrepreneurship and SMSs 2018. Retrieved from: https://ec.europa.eu/ info/sites/info/files/grow_aar_2018_final.pdf. [April 13, 2020]

European Commission, Cultural and creative industries. Retrieved from: https://ec.europa.eu/culture/policy/culturalcreative-industries_en. [April 5, 2020]

European Commission. (2019) The Creative skills Europ. Retrieved from: http://www.creativeskillseurope.eu/1073-2/. [April 5, 2020]

Eurostat, Cultural and creative emplyment. Retrieved from: https://appsso.eurostat.ec.europa.eu/nui/setupDownloads. do. [April 13, 2020]

Eurostat, Cultural statistics. Retrived from: https://ec.europa.eu/eurostat/documents/3217494/10177894/KS-01-19712-EN-N.pdf/915f828b-daae-1cca-ba54-a87e90d6b68b. [April 7, 2020]

Eurostat, Culture statistics - cultural employment. Retrieved from: https:/ec.europa.eu/eurostat/statistics-explained/ index.php?title=Culture_statistics. [April 7, 2020]

Harwiki, W., \& Malet, C. (2020) Quintuple helix and innovation on performance of SMEs within ability of SMEs as a mediator variable: A comparative study of creative industry in Indonesia and Spain. Management Science Letters, 10(6), 1389-1400. doi: 10.5267/j.msl.2019.11.018

Horvat, J., Mijoč, J., \& Lebeda, I. L. (2018). Otvorena inovativnost: indikatori i mjerenja. In Otvorenost u znanosti i visokom obrazovanju. Školska knjiga, Zagreb. 113-127. Retrieved from: https://www.bib.irb.hr/982492. [April 7, 2020]

Horvat, J., Mijoč, J., \& Zrnić, A. (2018) Ars Andizetum: treasury of projects supporting the creative industry by the Andizet. Osijek: Andizet. Retrieved from: https://www.andizet.hr/wp-content/uploads/2017/12/ArsAndizetum_HR-2. pdf. [April 7, 2020]

Ihani, W., Syofya, H., Sari, A. L., Mulawarman, W. G., \& Sriyanto, S. (2020) The Role of the Creative Industry in Economic Development. Journal of Environmental Treatment Techniques, 8(1), 268-271. https://doi.org/10.1007/978-3-31946319-3_5

Innerhofer, E., Pechlaner, H. \&Borin, E. (eds.) (2018) Entrepreneurship in Culture and Creative Industries: Perspectives from Companies and Regions. Springer International Publishing

Kaye, L. (2013). Laurence Kaye on Digital Media Law: Of content, technology and copyright. Retrieved from: https:// laurencekaye.typepad.com/laurence_kayes_blog/2013/10/index.html [June17, 2020]

KEA \& PPMI (2019) Research for CULT Committee - Culture and creative sectors in the European Union- key future developments, challenges and opportunities, European Parliament, Policy Department for Structural and Cohesion Policies, Brussels. Retrieved from: https://www.europarl.europa.eu/RegData/etudes/STUD/2019/629203/IPOL_ STU(2019)629203_EN.pdf. [April 7, 2020]

Khaire, M. (2018) Culture and commerce: the value of entrepreneurship in creative industries. Stanford Business Books 
I. Ljevak Lebeda, K. Mlinarević, J. Horvat: Atypical forms of work and business in the creative industry... Zbornik Veleučilišta u Rijeci, Vol. 9 (2021), No. 1, pp. 19-35

Landoni, P., Dell'era, C., Frattini, F., Petruzzelli, A. M., \& Manelli, L. (2019) Business model innovation in cultural and creative industries: Insights from three leading mobile gaming firms. Technovation, 102084. https://doi.org/10.1016/j. technovation.2019.102084

Majdúchová, H., \& Barteková, M. K. (2020) Innovations in the Creative Industry Entities. In SHS Web of Conferences 74, p. 02009. EDP Sciences. https://doi.org/10.1051/shsconf/20207402009

Mijoč, J. (2013) Modeliranje namjera za samozapošljavanje studentske populacije (Doctoral dissertation, Josip Juraj Strossmayer University of Osijek. Faculty of Economics in Osijek).

Petrova, L. (2018) Cultural Entrepreneurship in the Context of Spillovers Within the Cultural and Creative Industries. In Entrepreneurship in Culture and Creative Industries (pp. 197-211). Springer, Cham. https://doi.org/10.1007/978-3319-65506-2_11

Roszko-Wójtowicz, E., \& Białek,J. (2019) Measurement of the average innovativeness change over time in the EU member states. Journal of Business Economics and Management, 20(2), 268-293. https://doi.org/10.3846/jbem.2019.8337

Searle, N. (2017) Business Models, Intellectual Property and the Creative Industries: A Meta-analysis. CREATe Working Paper Series. DOI:10.5281/zenodo.808267

Strazdas, R., Cerneviciute, J., \& Jancoras, Z. (2013, December). Measuring of system innovation in the context of creative industry development. In ISPIM Innovation Symposium (p. 1). The International Society for Professional Innovation Management (ISPIM).

UNESCO. Creative industry in Slovakia. Retrieved from: https://en.unesco.org/creativity/policy-monitoring-platform/ creative-industry. [April 5, 2020]

Waldfogel, J. (2020) Digitization and Its Consequences for Creative-Industry Product and Labor Markets. In The Role of Innovation and Entrepreneurship in Economic Growth. University of Chicago Press.

WIPO. (2018) Dutta, S., Lanvin, B., \& Wunsch-Vincent, S. (Eds.). Global innovation index 2018: energizing the world with innovation. WIPO. Retrieved from: https://www.wipo.int/edocs/pubdocs/en/wipo_pub_gii_2018.pdf. [April 17, 2020]

WIPO. (2019) Dutta, S., Lanvin, B., \& Wunsch-Vincent, S. (Eds.). Global innovation index 2019: Creating Healthy LivesThe Future of Medical Innovation. WIPO. Retrieved from: https://www.globalinnovationindex.org/userfiles/file/ reportpdf/gii-full-report-2019.pdf. 
Izvorni znanstveni rad

https://doi.org/10.31784/zvr.9.1.2

Datum primitka rada: 16. 7. 2020.

Datum prihvaćanja rada: 8. 10. 2020.

\title{
ATIPIČNI OBLICI RADA I POSLOVANJA U KREATIVNOJ INDUSTRIJI EUROPSKE UNIJE
}

\author{
Ivana Ljevak Lebeda \\ Dr. sc., direktorica, Naklada Ljevak d. d., Chromosov toranj Ulica grada Vukovara 271, 10000 Zagreb, \\ Hrvatska; e-mail: ivana.ljevak@naklada-ljevak.hr
}

\section{Kornelija Mlinarević}

Mag. oec., pročelnica upravnog odjela za programe Eurospke unije Grada Osijeka, Grad Osijek, Kuhačeva 9, 31000 Osijek, Hrvatska; e-mail: kornelija.mlinarevic@osijek.hr

\section{Jasna Horvat}

Dr. sc., redovita profesorica u trajnom zvanju, Ekonomski fakultet u Osijeku, Sveučilište J. J. Strossmayera Osijek, Trg Ljudevita Gaja 7, 31000 Osijek, Hrvatska; e-mail: jasna@efos.hr

\section{SAŽETAK}

Polazeći od uvida u atipične oblike rada kao i nove/alternativne poslovne modele svojstvene sektorima kreativne industrije (KI) Europske unije, u radu se istražuje samozapošljavanje u kreativnoj industriji i volontiranje kao pretpostavka budućeg samozapošljavanja. Cilj ovoga rada utvrditi je atipične oblike rada u kreativnoj industriji Europske unije te poslovne modele s kojima su povezani. Kreativna industrija pri tome se drži industrijom ekonomski razvijenih zemalja te industrijom prototipa čije se „recepture“ umnažaju u nerazvijenim zemljama i tako opredmećuju za masovnu distribuciju. Metodologija rada primijenila je tri razlicite skupine metoda prilagođenih postavljenim hipotezama. Prva hipoteza navodi kako istraživanja Europske unije ukazuju na poslovna ograničenja/ karakteristike u kreativnoj industriji. S ciljem provjeravanja ove hipoteze meta analizom prikupljenih izvora izdvojena su ključna poslovna ograničenja u kreativnoj industriji, a zatim iz njih proistekli atipični oblici rada. Druga hipoteza provjerena je deskriptivnom i bivarijatnom statističkom analizom sekundarnih podataka. Riječ je o analiziranju sekundarnih podataka u novooformljenoj datoteci konstruiranoj za potrebe ovog istraživanja. U datoteci su objedinjeni sekundarni izvori podataka o kulturnoj statistici (Europske Unije) i Gll - globalni indeksi inovativnosti (WIPO) te su uporabljeni za provjeru hipoteze kako je samozapošljavanje kao atipičan oblik rada u kulturi povezano s razinom globalnog indeksa inovativnosti (GII).

Ključne riječi: kreativna industrija, poslovni modeli, meta analiza, atipični oblici rada, sekundarni podatci 
